\title{
COVID-19: Socioeconomic, Environmental, Psychological Effects, and Prediction Models
}

\author{
Sunil Jayant Kulkarni ${ }^{1}$ (D) \\ 1 Chemical Engineering Department, Gharda Institute of Technology, Maharashtra, India \\ * Correspondence: suniljayantkulkarni@gmail.com;
}

Received: 14.06.2020; Revised: 3.07.2020; Accepted: 5.07.2020; Published: 7.07.2020

\begin{abstract}
Infectious diseases are becoming a frequent nuisance for human beings. Aids, swine flue, COVID-19 are recent examples of this. Along with these diseases, natural calamities are challenging human existence. This is the result of ignoring the importance of sustainable development. Lack of awareness and forced efforts to overcome nature's powers may affect human beings in the long run. Unethical practices in technology must be stopped. Many people have become jobless due to COVID19 pandemic. The prolonged economic slowdown in many countries is resulting in human resources reduction in many organizations. Many people in private organizations may lose their jobs due to this pandemic. Indian private education system runs on admission and tuition fees. The youth is facing an uncertain future. There are some positive aspects like better air quality. The uncertainty has led to psychological disorders among the people. Isolation, which helps prevent the COVID-19, may be counterproductive for mental health. This paper is aimed at discussing various socio-economic, environmental, psychological, immunological effects on the human population. Also, it shed light upon investigations on prediction models.
\end{abstract}

Keywords: Pandemic; infection; diagnosis; jobs; quarantine; frustration.

(C) 2020 by the authors. This article is an open-access article distributed under the terms and conditions of the Creative Commons Attribution (CC BY) license (https://creativecommons.org/licenses/by/4.0/).

\section{Introduction}

The world today is threatened by coronavirus pandemic. It has an adverse effect on the economy, growth rate, and employment. Many people have lost their jobs. Still, it continues to spread in the world and is causing a large number of human casualties. The spread is fast and calls for a mechanism to predict future spread in order to create facilities to treat and isolate infected people. In India, as of today (June 2020), there are 4.2 lakh confirmed corona cases [1]. Around thirteen thousand peoples have lost their lives. Many peoples are quarantined to avoid the spread of the virus. On the positive side, about one lakh people have recovered. The health care facilities in India are flooded with patients. July onwards is the period of monsoon, which increases the health and waste disposal challenge. Many health workers, police staff and volunteers are working relentlessly to combat this disaster. The health of these people and the citizens, in general, is the major concern in the world. The reduction in air pollution index is the positive news along with a clean environment, water resources, seashores, and nature at large. This paper is aimed at discussing various socio-economic, environmental, psychological effects of the pandemic on the human population. Also, it sheds light on investigations on prediction models. The effects of changing food habits and living styles on immunity are also discussed by citing relevant literature. 


\section{Socio-economic Factors}

\subsection{Threats.}

COVID-19 is a fast-spreading virus. More than 1,136,849 people were infected with this globally as on April 5th, 2020[1]. As of June 22nd, this has grown to 8,860,331[2]. India has close to 427,046 infected people [1]. In India, about 55 percent of these people have recovered. The worldwide recovery rate is 54 percent. Since March 25th, India has declared a lockdown, which is gradually being relaxed in the first week of June. Government, citizens, and health workers are facing problems that don't have any history. There are no past incidences of such long lockdown across the country. Initially, when the lockdown was declared, people's movement was restricted. The government suspended all transportation facilities. Lakhs of workers in India work in the Metropolitan areas like Mumbai, Delhi, Calcutta, Chennai, Pune, etc. These workers were able to fulfill their daily needs from their savings for two-three weeks. When the savings were spent and income sources stopped, they had no any other option but to go to their villages as the living cost in Mumbai like the city is too high for them to stay back. There was much criticism of the authorities. We should understand that authorities make decisions based on available data and shared information. There were incidences of people walking hundreds of kilometers. The self-isolation facilities were also facing strange problems due to a lack of awareness and the absence of a sense of responsibility among people towards fellow citizens. The quality of self-discipline was found lacking in the people at the most difficult time. For each casualty, we must stop blaming the government. Many people in the private sector may lose their jobs and face salary cuts due to this pandemic. Colleges and schools come last in the list of opening up as the kids and youth gather in these areas. Indian private education system runs on admission and tuition fees, and it is facing an uncertain future due to prolonged lockdown.

\subsection{Strengths.}

Notwithstanding all the above problems and the lack of sense of responsibility among many citizens, the Indian educators, entrepreneurs, and technocrats have responded in excellent fashions. The schools and colleges realized the need for online teaching. Teachers become used to online teaching methods. Public hygiene awareness has increased. As the effect of this disaster, India realizes the need to spend more on health facilities. The government policies in the near future will surely address this problem. There were few incidences of taking political mileage, but broadly, all, the government, the authorities, municipalities, health care clinics are now more equipped to counter the viral diseases. This can be considered as a wake-up call to all concerned authorities and organizations to think about the health of people in the unorganized sector. Also, in healthcare policy, the responsibility of the health and hygiene of people working in the health sector should be fixed.

\section{Environmental Effects}

Solid waste management during and after this, pandemic needs to be handled carefully. This waste should be handled as per the guidelines of the Occupational Safety and Health Administration (OSHA) [3]. Use of personal protective equipment, proper segregation of waste can reduce the health hazard due to medical waste [4]. In India, the health ministry is conducting short term training programs to train the health workers about solid waste 
management for COVID related waste [5]. For solid waste, steam-based methods are better than incineration as the incineration gas may contain toxic and harmful emissions [6]. It is very important to ensure continuity in waste collection and ensure the periodic testing of the workers[6]. Also, the European Commission has created its guidelines for solid waste management during the pandemic [7]. The COVID-19 patient, according to these guidelines, should be provided with separate bags for solid waste. Such country or area-specific guidelines can address specific problems of that community or country than general guidelines by world bodies.

In many countries, the lockdown has resulted in better air quality. In China, the emission decreased to 75 percent in the last four months. European countries have also experienced clean air due to lockdown. Many touristic places regained their original beauty due to minimum human interference. The rivers, canals, and water reservoirs are back to their original beauty. Due to a drop in petroleum product demand, pollution due to refineries has decreased to some extent. Saadat et al. carried out studies on the environmental effects of COVID-19 outbreak[8]. The pollution due to vehicular emission has decreased drastically [8]. The lockdown condition has some blessings in disgust in India also. According to Gupta et al., the humidity has dropped to 40 percent, and particulate matter (PM2.5) has reached $40 \mathrm{~g} / \mathrm{m}^{3}[9]$. This period is a healing period for the environment when human activities are minimum, and the climatic conditions are maintained at their best.

The impact of COVID-19 on the household solid waste quantity in Morocco has been studied by Ouhsine et al. [10]. This investigation indicated that there was a change in solid waste quality during the lockdown. The solid waste reflected an increase in disinfectants, sanitizers, and a decrease in canned food and meat consumption. According to them, the mixing of PPE waste with household waste should be avoided, and people must be made aware of adverse effects due to improper handling of such waste.

The COVID crisis has brought a new perspective to the plastic usage policy. Most of the countries have banned the use of single-use plastic. In this crisis, the use of plastic has increased drastically. The use of plastic for various packaging, safety, and health kits has forced us to rethink the policy of banning plastics. According to Grodzińska-Jurczak et al., health concerns easily outweigh the environmental concerns in the minds of people and scientists also [11]. Plastic waste also has increased, and its treatment is now a more severe problem. Carbon emission due to carbon dioxide has already reached alarming levels [12].

Health and environmental issues are arising due to COVID-19 calls for help from world bodies like the world economic forum. Medical waste management needs to be upgraded. COVID-19 preparedness includes solid waste treatment facilities for healthcare institutions [13]. World bank is carrying out necessary measures through data collection and report preparation for sanctioning funds for countries like Bangladesh as a part of its policies to tackle COVID like crisis on a long term basis. The preparation of healthcare infrastructure and medical facilities is expected to be undertaken by these countries.

Abu-Qdais et al. discussed the rate of generation of medical waste in Jordan and model to predict the biomedical waste generation [14]. The waste generated was around 14 to $15 \mathrm{~kg}$ per patient per day. This rate, according to them, is ten folds of the normal rate. The frequent cleaning and changing of personal protective equipment have created the problem of solid waste management. There is a need to rationalize the use of PPE kit in the hospitals to minimize this problem. 


\section{Psychological Effects}

Many people are living away from their families due to lockdown. Overthinking about the progress, economy, job security can turn into a psychological disorder. Isolation, which helps prevent the COVID-19, may be counterproductive for mental health. It may cause depression and frustration. Post-traumatic stress among the people after lockdown and stress among the health care professional needs to be handled carefully. Mental, emotional, physical, and behavioral symptoms need awareness and proper counseling and medical, psychological treatment. Shete and Jadhav highlighted that ignoring the misinformation, avoiding watching COVID-19 related news, and involving in meditation can help to overcome the psychological effects of the pandemic [15]. Practicing Yoga can also increase mental stability and help in combating psychological disorders.

\section{Prediction Models}

Many statical models are proposed for forecasting the spread of the disease [16,17]. Tran et al. have proposed an Autoregressive integrated moving average (ARIMA) for predicting the spread of the virus[18]. They carried out the investigation based on data obtained in Iran as it is one of the worst affected countries due to COVID-19. The ARIMA model has been used in the past for the forecasting of diseases spread[19, 20]. This model was observed to be easy and accurate. According to studies carried out by Yadav et al., algorithm-based prediction of the COVID data can be made based on the daily average[21]. The next ten days' spread of the COVID-19 can be predicted by this method [21]. The artificial neural network model can also be used for data prediction, according to Tamang et al. [22]. Their prediction of around 1.28 lakh COVID-19 patients in India on May 18th, 2020, can be considered good enough to predict the data. The available data indicates around 96 thousand patients [23]. Though this is less than the predicted value, the credit goes to the doctors and other health workers for less infection rate. Also, the collection of real-time data has its disadvantages like non-reporting of the cases, lack of network in a certain area, and to some extent, noncooperation from the citizens.

\section{Human Immunity}

The effect of nutritional habits on Coronavirus infection was studied by Jeyaprakash et al. [24]. The immune system controls our body from external infection due to viruses and other hosts [24]. Maintaining adequate nutritional levels in the body is a very important aspect of the fight against such microorganisms. Vitamins A, B, C, and D have an important role in maintaining immunity. Also, zinc, arsenic, and other elements are required for the immune system. The nutritional level of COVID-19 patients after the infection should be checked before treatment. They are knowing the nutritional level of a person before infection can help to decide the immunity-boosting measures. Because of the modern lifestyle and amenities, the need for increasing immunity is felt. According to Tammineni, food habits and living style changes are contributing to immunity loss among youth and kids[25]. These changes, such as the use of air conditioners, food processors, washing machines, auto cleaners, have adversely affected the human immune system. The natural body movements are minimized, and deliberately, one has to look for physical exercise. The coronavirus infection causes pneumonia. Studies carried out by Malvade et al. suggests that, compared to the severe acute respiratory syndrome, coronavirus transmits faster and is more infectious [26]. Coronavirus 
varies in terms of risk factors. According to a study carried out by Selvamurugan, 30 percent of infected people can succumb to it in some cases [27]. Maintaining adequate nutritional levels in the body is a very important aspect of the fight against such microorganisms. This can be accomplished by planning our diet systematically and ensuring a sufficient intake of immunity boosters.

\section{Conclusions}

Government, citizens, and health workers are facing a problem that doesn't have any history. There are no past incidences of such long lockdown across the country. Initially, when the lockdown was declared, people's movement was restricted. The government suspended all transportation facilities. The use of personal protective equipment, proper segregation of waste can reduce the health hazard due to medical waste. The Health Ministry in India is conducting short term training programs to train the health workers about solid waste management for COVID related waste [28]. For solid waste, steam-based methods are better than incineration as the incineration gas may contain toxic and harmful emissions. In many countries, the lockdown has resulted in better air quality. Many people are living away from their families due to lockdown. Overthinking about the progress, economy, job security can turn into a psychological disorder. Isolation, which helps prevent the COVID-19, may be counterproductive for mental health. Ignoring the misinformation, avoiding watching COVID19 related news, and involving in meditation and practicing Yoga can help to overcome the psychological effects of the pandemic. The immune system controls our body from external infection due to viruses and other hosts. Maintaining adequate nutritional levels in the body is a very important aspect of the fight against such microorganisms. This can be accomplished by planning our diet systematically and ensuring a sufficient intake of immunity boosters.

COVID-19 has caused infection in children due to contact with adults. These infections were low risk compared to infections in adults[29]. Investigations are being done to find inhibitors from different plats for the viruse[30]. Public awareness about cleaning and maintaining good hygienic conditions at home at the workplace, along with prompt treatment, can help to reduce the spread of diseases [31]. Investigations in the medical and pharmaceutical field are aimed at finding antibacterial agents and inhibitory drugs for various diseases[32-34]. Investigations on COVID-19 are expected to result in the synthesis of antiviral drugs and vaccines.

\section{Funding}

This research received no external funding.

\section{Acknowledgments}

The author acknowledges the encouragement and support of the affiliating institute.

\section{Conflicts of Interest}

The authors declare no conflict of interest.

\section{References}

1. Government of India, (2020). Arogya setu app. https://www.mygov.in/aarogya-setu-app/ 
2. Who, 2020. Coronavirus (COVID 19) disease pandemic. https://www.who.int/docs/defaultsource/coronaviruse/situation-reports/20200622-covid-19-sitrep-154.pdf?sfvrsn=d0249d8d_2

3. Forms 300, 300A, 301 and Instructions, OSHA. https://www .osha.gov/recordkeeping /RKforms .html

4. Healthcare Waste Institute,2020. Frequently asked questions 2019 Novel Coronavirus. https://www.cdc.gov/coronavirus/2019-ncov/faq.html

5. Health Care Without Harm. Health care waste management: Coronavirus update. https://noharmglobal.org/sites/default/files/documents-files/6339/HCWH\%20COVID-19\%20Waste\%20Facts_0.pdf(2p)

6. International Solid Waste Association, Waste management during the COVID-19 pandemic ISWA's recommendations.

https://www.iswa.org/fileadmin/galleries/0001_COVID/ISWA_Waste_Management_During_COVID19.pdf (12 p.) 2020

7. European commission. Waste management in the context of the coronavirus crisis. 2020. https://ec.europa.eu/info/sites/info/files/waste_management_guidance_dg-env.pdf , 5p.

8. Saadat, S.; Deepak Rawtani, D.; Chaudhery M.H. Environmental perspective of COVID-19, Science of the Total Environment 2020, 728, 1-6, https://doi.org/10.1016/j.scitotenv.2020.138870.

9. Gupta, N.; Tomar, A.; Kumar, V. The effect of COVID-19 lockdown on the air environment in India. Global J. Environ. Sci. Manage 2020, 6(SI), 31-40.

10. Ouhsine, O.; Ouigmane, A.; Layati, E. Aba, B.; Isaifan, R.J.; Berkani, M. Impact of COVID-19 on the qualitative and quantitative aspect of household solid waste. Global J. Environ. Sci. Manage. 2020, 6, 4152, https://doi.org/10.22034/GJESM.2019.06.SI.05.

11. Grodzińska-Jurczak, M.; Krawczyk, A.; Jurczak, A.; Strzelecka, M.; Boćkowski, M.; Rechciński, M. Environmental choices Vs. COVID-19 pandemic fear - plastic governance re-assessment. Society Register 2020, 4, 49-67, https://doi.org/10.14746/sr.2020.4.2.04.

12. World Economic Forum, 2016. The New Plastics Economy - Rethinking the future of plastics. World Economic Forum, Ellen MacArthur Foundation and McKinsey \& Company.

13. The World Bank, 2020. COVID-19 Emergency Pandemic Preparedness and Response Project (P173757). 03/21/2020 | Report No: ESRSA00546.

14. Abu-Qdais, H.A.; Al-Ghazo, M.A.; Al-Ghazo, E.M. Statistical analysis and characteristics of hospital medical waste under novel Coronavirus outbreak. Global J. Environ. Sci. Manage.2020, 6, 21-30, https://doi.org/10.22034/GJESM.2019.06.SI.03.

15. Shete, S.K.; Jadhav, S.P. A review on psychological impact of COVID -19. World Journal of Pharmaceutical and Life Science 2020, 6, 63-69.

16. Roosa, K.; Lee, Y.; Luo, R.; Kirpich, A.; Rothenberg, R.; Hyman, J.M.; Yan, P.; Chowell, G. Real-time forecasts of the COVID-19 epidemic in China from February 5th to February 24th, 2020. Infect. Dis. Model. 2020, 5, 256-263, https://doi.org/10.1016/j.idm.2020.02.002.

17. Chintalapudi, N.; Battineni, G.; Amenta, F. COVID-19 virus outbreak forecasting of registered and recovered cases after sixty day lockdown in Italy: A data driven model approach. Journal of Microbiology, Immunology and Infection 2020, 53, 396-403, https://doi.org/10.1016/j.jmii.2020.04.004.

18. Tran, T.T.; Pham, L.T.; Ngo, Q.X. Forecasting epidemic spread of SARS-CoV-2 using ARIMA model (Case study: Iran). Global J. Environ. Sci. Manage 2020, 6, 1-10, https://doi.org/10.22034/GJESM.2019.06.SI.01.

19. Alsharif, M.H.; Younes, M.K.; Kim, J. Time series ARIMA model for prediction of daily and monthly average global solar radiation: The case study of Seoul, South Korea. Symmetry 2019, 11, 240-258, https://doi.org/10.3390/sym11020240.

20. Tran, Q.N.; Arabnia, H. Emerging trends in computational biology, bioinformatics, and systems biology: algorithms and software tools. Ed., New York, Elsevier/Morgan Kaufmann 2015. pp. 670.

21. Yadav, D.; Maheshwari, H.; Chandra, U. Outbreak prediction of COVID-19 in most susceptible countries. Global J. Environ. Sci. Manage. 2020, 6, 11-20, https://doi.org/10.22034/GJESM.2019.06.SI.02.

22. Tamang, S.K.; Singh, P.D.; Datta, B. Forecasting of COVID-19 cases based on prediction using artificial neural network curve fitting technique. Global J. Environ. Sci. Manage. 2020, 6, 53-64, https://doi.org/10.22034/GJESM.2019.06.SI.06.

23. Indian Express, 2020. Coronavirus updates. https://indianexpress.com/article/india/coronavirus-COVID-19india-updates-18-may-corona-cases-deaths-recoveries-today-update-6415582/

24. Jeyaprakash, K.; Velavan, S.; Ganesan, S.; Arjun, P. Impact of nutritional interventions on corona virus infection - review article. World Journal of Pharmaceutical and Life Science 2020, 6, 76-80.

25. Tammineni, Y. Health hazards of modern living - a perspective study. World Journal of Pharmaceutical and Life Science 2020, 6, 81-86.

26. Malvade, P.V.; Malvade, R.V.; Varpe, S.P.; Kadu, P.B. The Novel Coronavirus (COVID-19) causative agent for human respiratory diseases. World Journal of Pharmaceutical and Life Sciences 2020, 6, 152-161.

27. Selvamurugan, S. Current scenario on COVID-19: a review. World Journal of Pharmaceutical and Life Science 2020, 6, 87-91.

28. Ministry of health and family welfare, 2020. National training for trainers for COVID 19, Environmental cleaning, disinfection and bio-medical waste management. New DELHI March 6th 2020, pp. 31 p. 
29. Alsayed, R.; Kadhom, M.; Yousif, E.; Sabir, D. An Epidemiological Characteristic of the COVID-19 Among Children.Letters in Appl. Nanobioscience 2020, 9, 1136-1164.

30. Monajjemi, M.; Mollaamin, F.; Shojaei, S. An overview on Coronaviruses family from past to COVID-19: introduce some inhibitors as antiviruses from Gillan's plants. Biointerface Research in Applied Chemistry 2020, 10, 575-1585, https://doi.org/10.33263/BRIAC103.575585.

31. Hadi, A.G.; Kadhom, M.; Hairunisa, N.; Yousif, E.; Mohammed, S.A. A Review on COVID-19: Origin, Spread, Symptoms, Treatment, and Prevention. Biointerface Research in Applied Chemistry 2020, 10, 72347242.

32. Fernandes, R.T.S.; França, E.L.; Triches, D.L.G.F.; Fujimori, M.; Machi, P.G.F.; Massmman, P.F.; Tozetti, I.A.; Honorio-França, A.C. Nanodoses of melatonin induces apoptosis on human breast cancer cells cocultured with colostrum cells. Biointerface Research in Applied Chemistry 2019, 9, 4416-4423, https://doi.org/10.33263/BRIAC95.416423.

33. Hassabo, A.G.; Mohamed, A.L. Novel flame retardant and antibacterial agent containing mgo nps, phosphorus, nitrogen and silicon units for functionalise cotton fabrics. Biointerface Research in Applied Chemistry 2019, 9, 4272-4278, https://doi.org/10.33263/BRIAC95.272278.

34. Hozeifi, S.; Abedi, F.; Beydokhti, H.; Farkhondeh, T.; Samarghandian, S.; Atabati, E. An updated systematic review on the applied tst and igra test for diagnosing ltbi in patients treated with tnf- $\alpha$ inhibitor drugs. Biointerface Research in Applied Chemistry 2019, 9, 4485-4493, https://doi.org/10.33263/BRIAC96.485493. 